\title{
Aspects of Iconography in Byzantine Cappadocia
}

\author{
E. Ene D-Vasilescu
}

\section{ABSTRACT}

The main novelty my article brings concerns a particular iconographic motif: that known as the 'trial by the water of reproach'. In the few cases where this is rendered, usually only Mary is presented as undergoing this test, but in Cappadocian art Joseph is also subjected to it.

Additionally, to this visual topic, another one that is rarely depicted will be introduced and commented upon: that known as 'Christ's first bath'. I will provide a particular example: the fresco which constitutes part of the decoration that embellishes the walls of Karabaş Kilise/ 'The Big Church' in Soğanlı Valley, southern Cappadocia.

A few images - one of them never published before - have been included within this publication.

Keywords: Byzantium, Byzantine frescoes, Cappadocia, Constantine VII Porphyrogenetus. Karabaş church in the Soğanlı Valley, Phocas family, the Old and New Tokalı churches in Göreme.

\section{INTRODUCTION}

The current piece is concerned with two rare visual motifs that can be found among other images which decorate churches established in Cappadocia under Byzantine rule. These visual topics are known as the 'trial by the water of reproach' and 'Christ's first bath'.

With respect to the first, in most places where it is rendered, only Mary appears to be tested. But in the cases I present here, the Old Tokalı Church (with a fresco from the early tenth century), and the New Tokalı (embellished at the end of the tenth century), Joseph is also subjected to the trial. This is one novelty which my article brings into the field of Byzantine Studies. Additionally, to this iconographic motif, my piece shows and comments on an image that has not been published before and which represents another rare visual topic - that of 'Christ's first bath' - which is a part of the decoration that beautifies the walls of Karabaş Kilise. These two iconographic topics originate in the apocryphal texts of the Protoevangelion of James and the Gospel of PseudoMatthew.

\section{A SHORT HISTORY OF CAPPADOCIA BEFORE THE BYZANTINE RULE}

Between the second and the first millennium $\mathrm{BC}$, the area we call now Cappadocia was the seat of the Hittite Empire, and then, in the sixth century BC (546-334 BC), it came under the Achaemenids, who divided it in two satrapies. The earliest documentation of the name "Cappadocia" dates from this period; the word meant the country of beautiful horses. The territory was recorded by the inscriptions of two early kings of that Empire, Darius I (550-486 BC; ruled in 522-486 BC), and Xerxes I (d. 465; ruled 486-465 BC). According to Herodotus, at the time of the Ionian Revolt (499 BC), the
Cappadocians occupied a region from Mount Taurus (Fig. 1) to the vicinity of the Pontus Euxine (the Black Sea) [1]. Therefore, the province was bordered in the south by the Taurus Mountains that separate it from Cilicia to the east by the upper Euphrates, to the north by Pontus, and to the west by Lycaonia and eastern Galatia.

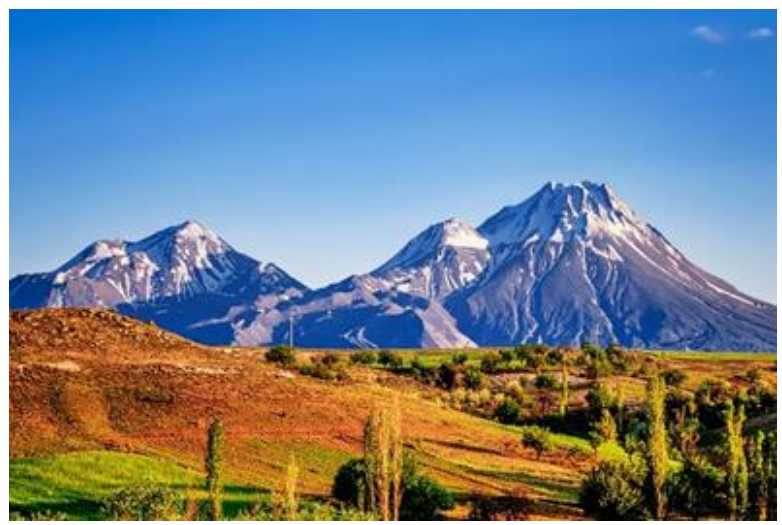

Fig. 1. Mount Taurus. Source for the image [2]

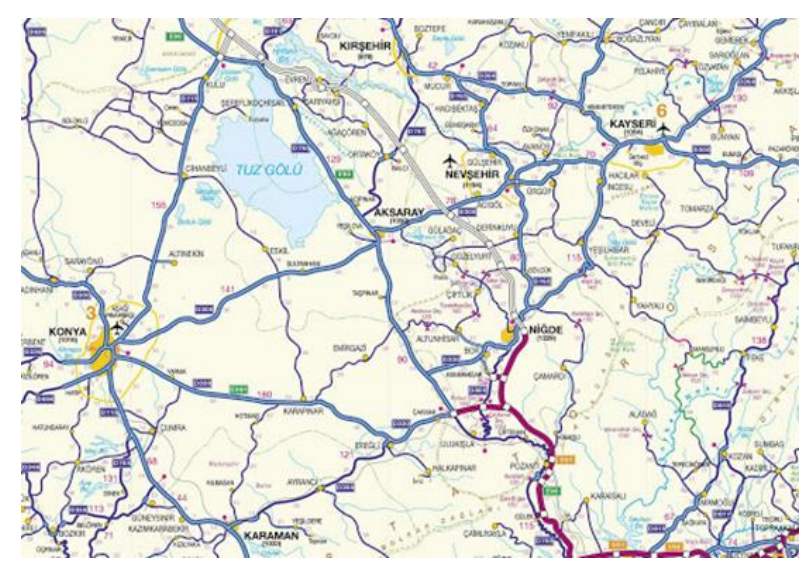

Fig. 2. Map of Cappadocia today. Source: Cappadociaturkey.net; the access to these images is licensed under the Creative Commons Attribution 3.0 Generic. 
The territory (Fig. 2) was conquered by the Greeks and then by the Romans and became an important theme of the Byzantine Empire, often raided by the Arabs between the seventh and eleventh centuries AD. In 314 Cappadocia was the largest province of the Roman Empire and was part of the Diocese of Pontus. In 371 the western part of the province was divided into Cappadocia Prima, with its capital at Caesarea (modern-day Kayseri) ${ }^{1}$, and Cappadocia Secunda, with its capital at Tyana. By 386, the area to the east of Caesarea had become part of Armenia Secunda, while the northeast region belonged to Armenia Prima. Cappadocia largely consisted of big estates owned by the Roman emperors and wealthy local families. It became more important in the second part of the fourth century as the Romans had disputes with the Sasanian Empire over the control of Mesopotamia and of the Armenian territories beyond the Euphrates. Cappadocia of that period is documented by the use of Iranian fire worship, which is attested in 465 [3].

\section{THE BYZANTINE PERIOD OF CAPPADOCIA}

As announced, we concentrate in the article on the period when Cappadocia was a part of the Byzantine Empire; a map of the province at that time is in Fig. 3. For most of the Byzantine time the area was not involved in the conflicts with the Sassanid Empire that were taken place in the surroundings; nevertheless, as intimated above, it constituted an important frontier against the Arab attacks. The province was conquered by the Seljuk Turks at the end of the eleventh century - Caesarea, still the capital, fell in 1082 - and became Ottoman territory.

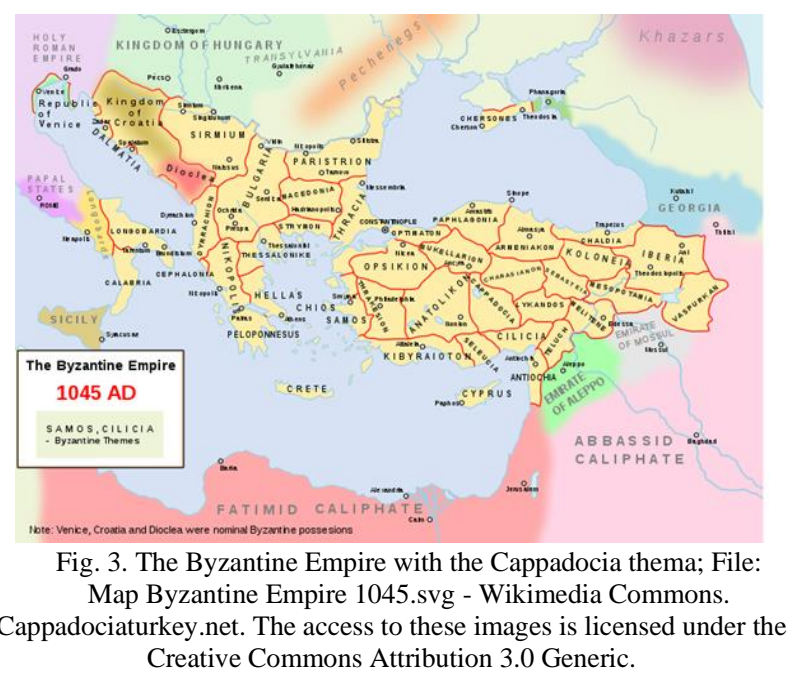

Between the sixth and the eleventh century ecclesiastical iconography that was predominant in the area because of the multitude of churches that existed - more than seven hundred [4] - followed the painting traits peculiar to the rest of the Empire.

\footnotetext{
${ }^{1}$ Another Caesarea exited and its ruins are on the Mediterranean in today Israel, two kilometres from Haifa. That was known as Caesarea Palestinae Maritima, was established in c. 9 BCE, during Herod's rule, and constituted the provincial capital of Roman Judea, Roman Syria Palaestina, and Byzantine Palaestina Prima.

${ }^{2}$ In reference $6 ;$ the author specifies that the frescoes were accomplished by Saint-John de Güllü dere in 913-920. She adds that those in the north-east niche are "probably anterior to those in the south-east".
}

The peak of its development was between the tenth and the eleventh centuries; the best surviving imagery is from this period that was marked by the ruling of the Phocas family. Nicephoros (Nikephoros) II Phokas was born in Cappadocia in 912 and became the sebastokrator of the Anatolikon thema in 945 under Constantine VII Porphyrogenetus (reigned 913959). As we know, he was proclaimed emperor by his troops in Caesarea, crowned in Constantinople [5], and reigned between 963 and 969. Nicephoros's father, the general Bardas Phocas (878 - 968 AD), began the construction of the New Tokalı church; Caterine Jolivet-Lévy mentions also his son Constantine when referring to the foundation of this monument. Other members of Phocas family (perhaps Bardas's two other sons or his brothers - they have the same names - Leon and Nicephoros) completed it and had it decorated; some of the frescoes there were painted in lapislazuli; also, gold and silver were used in various parts of the decoration. The representatives of Phocas family established many churches in the area, and inscriptions to prove this fact have survived; one such evidence exists within Kılıçlar Kilise (the church of swords; tenth century) where Nicephoros's name is mentioned. In the article published in 2019 I indicated other places where he is named as the founder: New Tokalı and the Pigeon House (Dovecote) at Çavuşın, 964-965 $\mathrm{AD}$ (where he is depicted with his wife Theophano and other members of the family).

Within the above-mentioned text, I have also indicated other places where Byzantine funders are mentioned: emperors Basil II (976-1025) and Constantine VII Porphyrogenetus in St. Barbara/Tahtala Church, Soğanlı Valley in an inscription from the eleventh century. The first Byzantine emperor himself, Constantine (c. 272-337; ruled 306-337), is depicted in El Nazar church, which dates to the tenth century.

\section{RARE ICONOGRAPHIC MOTIFS IN CAPPADOCIAN BYZANTINE CHURCHES}

Among the iconographic motifs which I remarked in my article there is one which I encountered in a fresco within Kokar Church: Christ on the cross clothed. It was painted between the second half of the ninth century and the second half of the eleventh century [6]. In the same piece I gave two examples that represent a rare visual subject-matter: a particular rendering of Mary and Joseph's Flight to Egypt; it is not necessary to present them here again ${ }^{2}$. What is specific in Cappadocia with regard to the depictions of this scene is the fact that a young man leads the donkey on which Mary travels; he was sometimes considered to be James, Christ's half-brother. Such a scene is depicted in the Old Tokal church, Göreme ${ }^{3}$ (tenth century ${ }^{4}$ ) and in Pürenlı Seki Kilisesi (Pürenlı Church), of which decoration had been attributed to the period between the second half of the ninth century and the second half of the eleventh century ${ }^{5}$. The same episode is

${ }^{3}$ In reference 6; the author specifies that the frescoes were accomplished by Saint-John de Güllü dere in 913-920. She adds that those in the north-east niche are "probably anterior to those".

${ }^{4}$ Tokali Church - The local dating is seventh century, with another layer from the tenth beginning of the eleventh century.

${ }^{5}$ In reference 6; p. 303 and p. 305; on the latter page the researcher makes a note with respect to the controversies surrounding such a dating. 
present in Sarnic Church, eleventh century, and the church of Avalar (the church of the cistern), even though the local notices within the building say that the fresco represents Mary and Joseph's journey to Bethlehem.

\section{THE ICONOGRAPHICAL MOTIF CONCERNING THE DRINKING OF THE WATER OF REPROACH}

Another uncommon motif to be found in Byzantine iconography is that known as the trial of Mary for scandalous conduct. In my previous article about Cappadocia, I only mentioned it, but did not show images of it. This ordeal is described in the Bible at Numbers 5. 11-316 [7] and mentioned in the Protevangelium of James as well as in the Gospel of Pseudo-Matthew. According to the apocryphal story of Mary's life, she was subjected by the High Priest to questions regarding the truth of her virginity after becoming pregnant [8], [9]. During this hearing she was tested by being asked to drink bitter water - 'the water of reproach' - and the result of such an act proved that she, hence also Joseph, were innocent. The scene is rarely represented in iconography, and when it is, it refers to Mary being tested; in the Cappadocian context this visual subject-matter is to be found, for instance, in the churches of St. Eustathios (the ninth century?), Aynali (eleventh century) ${ }^{7}$, Bahattin' in Samanlığ 1 (c. 1000 AD) $)^{8}$, and Kiliçlar (mid tenth century) ${ }^{9}$ [11]. The scene is also depicted in the Old and the New Tokalı churches within the Göreme Valley, where I have seen it myself [12]. In their case Joseph is also represented as undergoing the trial by water; Fig. 4.

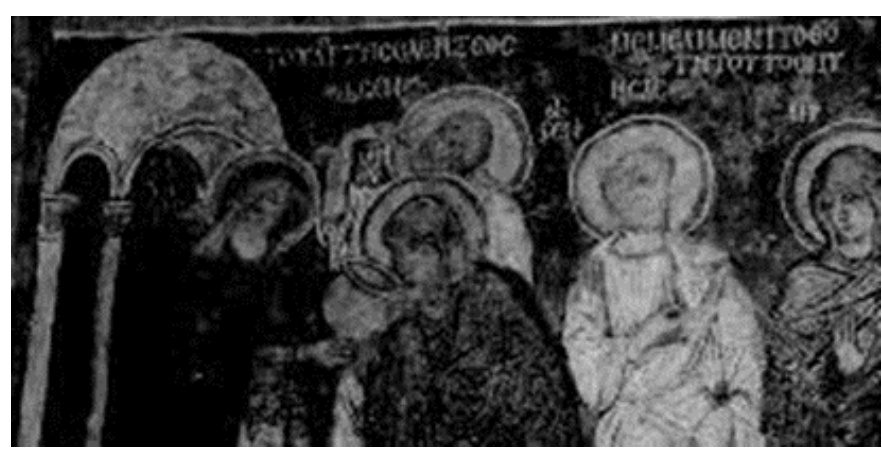

Fig. 4. Mary and Joseph drinking the water of reproach; fresco in Old Tokalı, early tenth century [8].

The narration within the Protevangelium of James in which this image originates is as follows:

And the priest said (to Joseph): 'Give back the virgin whom you have received from the temple of the Lord.' And Joseph began to weep. And the priest said: 'I will give you both to drink the water of conviction of the Lord, and it will make your sins manifest in your eyes.' And the priest took it and gave it to Joseph to drink and sent him into the hill-country, and he returned whole. And he made Mary drink also, and sent her into the hill-

${ }^{6}$ Elizabeth Jeffreys mentioned this scene in her paper entitled "The Homilies of James of Kokkinobaphos in their twelfth-century context", delivered at the seventeenth International Conference of Patristic Studies, Oxford, 2015.

${ }^{7}$ Aynalı Church has a plan floor common to c. 500 AD. Its painting, without the typical frescoes with human characters, but rendering only country, and she returned whole. And all the people marvelled, because sin did not appear in them. And the priest said: 'If the Lord God has not revealed your sins, neither do I judge you.' And he released them. And Joseph took Mary and departed to his house rejoicing and glorifying the God of Israel." (Protevangelium of James 16) [13]-[15].

In the Gospel of Pseudo-Matthew, after drinking the "water of reproach", Mary and Joseph are asked to go seven times around the altar [13], [14].

The motif is represented as early as the sixth century on the throne of Maximianus made of ivory plaque, and today in the Museo Arcivescovile, Ravenna as well as on a cover of a Gospel, and also in an ivory (relief) to be found in the Bibliothèque Nationale, Paris [8].

As we can see in the Figure 4 above, the group involved in the story comprises, additionally to Mary and Joseph, who are represented drinking the water, the High Priest and two more elderly men. The priest could be Zachariah, St. John's father; in some versions of the Protoevangelium he is designated as performing the task we discuss [13], [14]. From what we can see here, and especially from what I saw in terms of colour, the participants are dressed in the traditional religious Byzantine attire suited for such a festive moment, mainly cloaks; Mary wears a red maphorion, Joseph a cloak, and the others mantles of various colours.

In the fresco from the New Tokali only Mary and Joseph are presented; she is enveloped in the usual red maphorion and he wears his habitual cloak, which in the Byzantine iconography that renders him, usually is white, as in the case of our concern. Unfortunately, the painting on their faces has not survived, hence we cannot describe their expression.

Serap Yüzgüller Arsal, Professor of Art History at the University of Istanbul, in an article published in 2009, differentiates between East and West when speaking about the circulation of the iconographic motif of trial "by the water of reproach" [8]. She thinks that its transmission is more notable in the part of Europe that was under the influence of the Byzantine Empire, the Eastern part. But from the research I have undertaken on this topic, especially when looking for apocryphal material for one of my books [18],[19], it does not seem to be a differentiation between the Eastern and Western distribution of this visual theme - this is represented rather scarcely in both parts of Europe. The only variation is that in the East 'the trial by water' appears especially in frescoes, while in the West, as we have just seen (in the case of the imperial throne of Maximianus and the book from Paris), in other media.

\section{THE ICONOGRAPHICAL MOTIF OF CHRIST’S FIRST BATH}

Continuing with an iconographic motif which also involves water, as remarked at the outset of this paper, among other rare topics in the Cappadocian churches is what is

crosses, dates from Iconoclastic period (726-843), when such a manner of decoration was the norm.

${ }^{8}$ For the list of these churches see the reference 10. Bahattin' in Samanlığ Church might have been funded in c. $1000 \mathrm{AD}$; its frescoes are painted in the Byzantine style of the middle tenth century- first half of the eleventh.

${ }^{9} \mathrm{~K}$ ilıçlar Church is in Kilıçlar Valley, which is near Göreme Open Air Museum. 
known as 'Christ's first bath'. I have come across it in Karabaş Kilise/ "The Big Church", Soğanlı Valley (southern Cappadocia) (Fig. 7 a, b) [20]. The church has four main rooms; the one where this scene is painted has three layers of frescoes. The local notice placed in the church states that the first layer of painting is from the seventh century, and the two subsequent ones from the eleventh and thirteenth centuries. The inscription above the church door mentions the date of foundation as 1060-1061. The donors are named as the Protospatharios Michael Skepides ${ }^{10}$, the nun Katherine, and the monk Nyphonos.

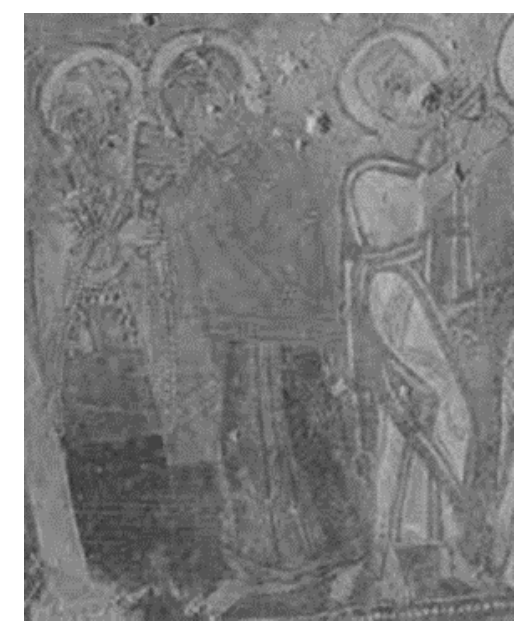

Fig. 5. Mary and Joseph drinking the water of reproach; fresco in New Tokalı, the end of the tenth century. The access to these images is licensed under the Creative Commons Attribution 3.0 Generic. My own colour photos still undergo processing [8].

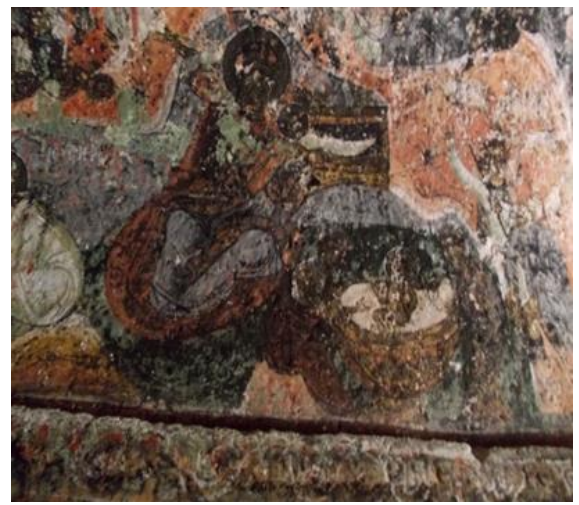

(a)

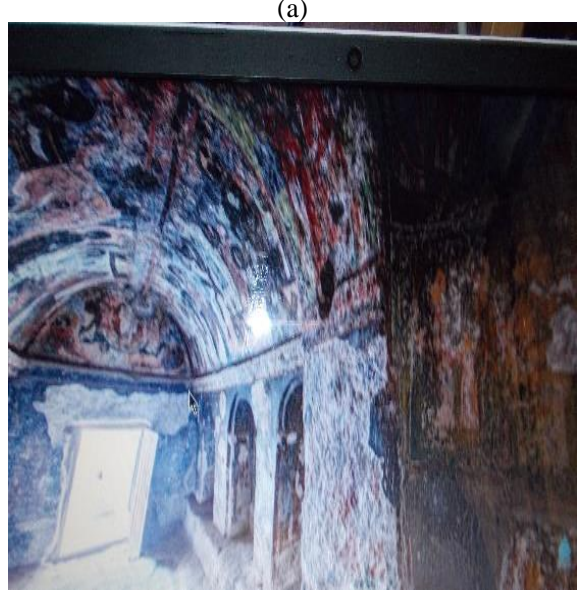

(b)

Fig. 6. The scene of Christ's first bath in Karabaş Kilise / "The Big Church", Soğanlı Valley, southern Cappadocia; my own photo, May 2015.

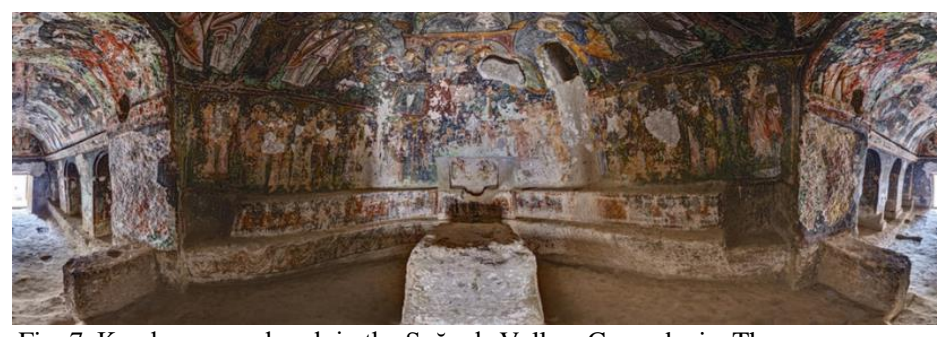

Fig. 7. Karabaş cave church in the Soğanlı-Valley, Cappadocia. The access to these images is licensed under the Creative Commons Attribution 3.0 Generic [22].

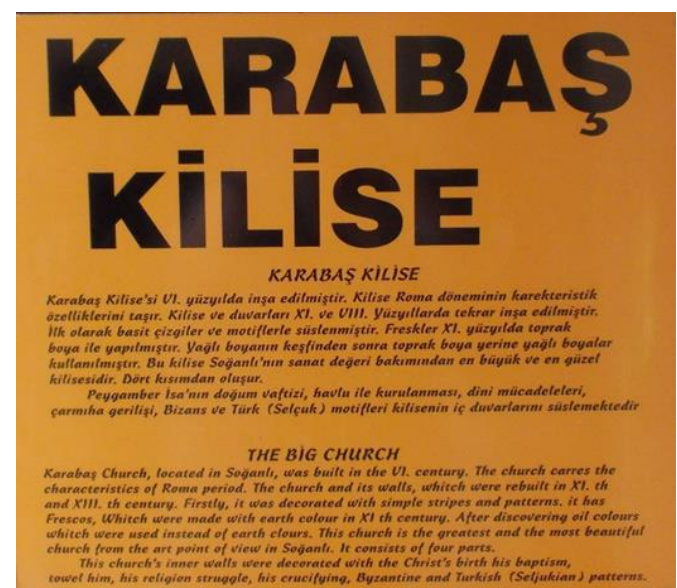

Fig. 8. Karabaş cave church in the Soğanlı Valley, Cappadocia; photos taken by EED-V, May 2015 [22].

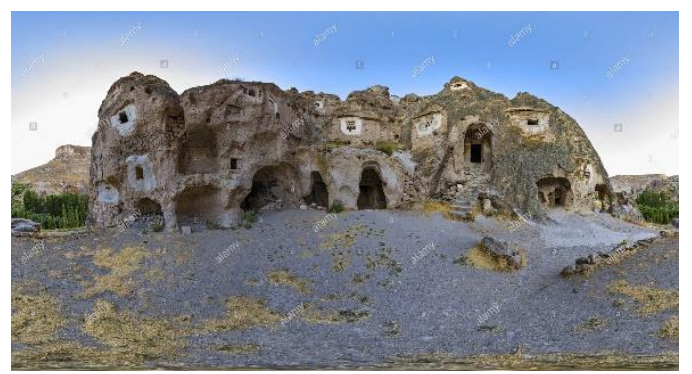

Fig. 9. Exterior view Karabaş cave church in the Soğanlı Valley [22].

At Karabaş, where I saw the painting myself in May 2015, the scene of the first bath, is introduced, as is to be expected, as a part of the cycle regarding Christ's childhood. Here, like in other Cappadocian churches founded earlier, the painting does not, as a rule, follows what was to become the usual typicon of Byzantine iconography (with particular scene situated in particular places), but goes in an order chosen by the iconographer. Usually, it starts at a corner of the church and continues on the walls, and also on the ceiling. The scene of the first bath depicted in Karabaş contains two episodes: in the first one we can see Mary and the child; in the second, the figure of Salome is noticeable; the midwife is bathing the child in a vessel [21]. From what can be observed today on the ceiling at Karabaş, the faces and the attire of the persons involved in the event are presented in a traditional manner from all points of view.

Hüseyin Metin and Salih Soslu, in the article "The Altıkapılı Cave Church at Pisidia" published in 2018, describe the same scene he found in Alt1kap1lı Church in the town named in their title [22]. This unusual visual topic originates in Genesis (Gen. 1.20), where it is connected with the water's property to create life. Notably Pseudo-Dionysios

${ }^{10}$ Skepides family was a well-known family in the eleventh century. 
(sixth century) refers to the baptism as to a 'ceremony of divine generation' $(\theta \varepsilon o \gamma \varepsilon v \varepsilon \sigma i ́ \alpha)^{11}$ [23], [24]; Byzantine iconography abundantly represents water as a source of life especially until the twelfth century; such a subject-matter evokes life.

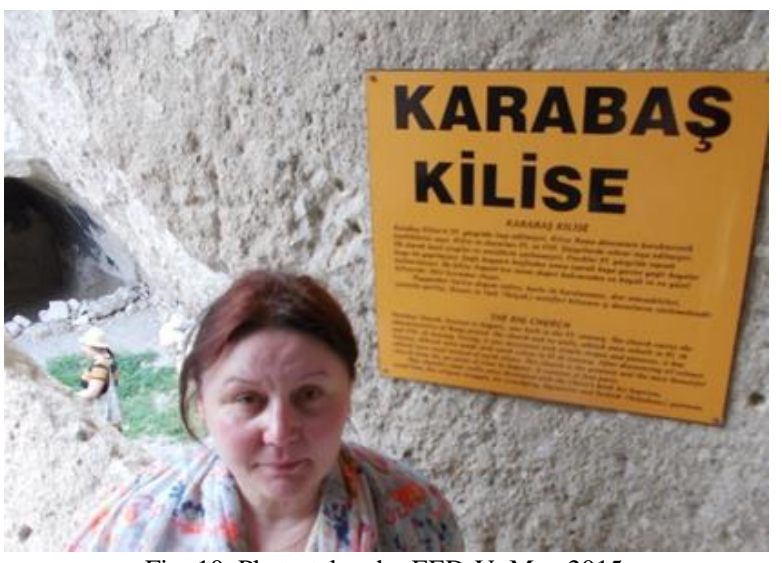

Fig. 10. Photo taken by EED-V; May 2015.

To conclude: the two iconographic topics on which we have elaborated enrich the information we have about Cappadocian religious iconography and about the Byzantine Empire.

\section{REFERENCES}

[1] Dewald, C. Introduction to Herodotus: The Histories. Translated by Robin Waterfield, 1998

[2] https://en.wikipedia.org/w/index=Taurus_Mountains.

[3] Nicholson, O. "Oliver Nicholson (ed.). The Oxford Dictionary of Late Antiquity." Abstracta Iranica. Revue bibliographique pour le domaine irano-aryen, 40(41), 2019.

[4] Ousterhout, RG, "A Byzantine Settlement in Cappadocia, Dumbarton Oaks Studies 42." Washington, D.C.: Dumbarton Oaks Research Library and Collection and Harvard University Press, revised edition 2011.

[5] Dagron G. and H. Mihăescu. "Le traité sur la guérilla (De velitatione) de l'empereur Nicéphore Phocas." Paris: Centre National de la Recherche Scientifique, 1986.

[6] Jolivet-Lévy, C. "Les églises byzantines de Cappadoce: le programme iconographique de l'abside et de ses abords." Paris: Éditions du Centre national de la Recherche scientifique CNRS, 1991.

[7] The Holy Bible, King James Version, Nelson Bibles, pp. 125-126.

[8] Yüzgüller Arsal, S. "A Scene from Asia Minor: The Trial by Water", in Synergies.Turquie, no 2, 51-57, 2009.

[9] Jeffreys, E. The Homilies of James of Kokkinobaphos in their TwelfthCentury Context, 2015.

[10] Ötüken, SY. Ihlara vadisi (Vol. 33). Kültür Bakanlığı, 1990.

[11] Cave, JA. "The Byzantine Wall Paintings of Kiliclar Kilise: Aspects of Monumental Decoration in Cappadocia (Medieval Art History; Middle East)." The Pennsylvania State University, 1984.

[12] Ötüken, Y. Göreme, Kültür ve Turizm Bakanlı̆̆ 1 Yayınları, 1987.

[13] Elliott, JK. "The Apocryphal New Testament." A Collection of Apocryphal Christian Literature in an English Translation, Oxford: Oxford University Press, 2005.

[14] Elliott, JK. "A Synopsis of the Apocryphal Nativity and Infancy Narratives." Leiden and Boston: Brill, 2006.

[15] Cartlidge, DR. and Elliott, JK. "Art and the Christian Apocrypha." London: Routledge, 2001.

[16] D-Vasilescu, EE. "Heavenly Sustenance in Patristic Texts and Byzantine Iconography: Nourished by the Word." Springer, 2018.

[17] D-Vasilescu, EE. (Ed.). Devotion to St. Anne in Texts and Images: From Byzantium to the Late European Middle Ages. Springer, 2018.

\footnotetext{
${ }^{11}$ We should note that although the word is not translated as such, it could mean 'reborn again through God', see PG 3:393A. For the meaning of ' $\theta \varepsilon$ o $\varepsilon v \varepsilon \sigma i \alpha$ ', see the reference [25]. The word Pseudo-Dionysios uses for the sacrament of Baptism is not 'Baptism' but 'divine birth' ( $\theta \varepsilon \sigma \gamma \varepsilon v \varepsilon \sigma i ́ \alpha)$,
}

[18] Ousterhout, RG. "Visualizing Community: Art, Material Culture, and Settlement in Byzantine Cappadocia." Dumbarton Oaks Studies 46, Washington, D.C.: Dumbarton Oaks Research Library and Collection and Harvard University Press, 2017.

[19] https/www.360cities.net/image/karabas-cave-church-in-the-soganlivalley-cappadocia-turkey.

[20] www.alamy.com.

[21] Thierry, N. "Etude Stylistiquedes Peintures de Karabaş Kilise en Cappadoce (1060-1061)", Cahiers Archeologiques XVII: 161-175, 1967.

[22] Metin, H. "The Altkkapılı Cave Church at Pisidia", in Adalya 21, pp. 315-333, 2018

[23] Dionysius the Areopagite/Pseudo-Dionysius, Corpus Dionysiacum II Pseudo-Dionysius Areopagita De coelesti hierarchia, De ecclesiastica hierarchia, De mystica theologia, Epistulae, edited by Günter Heil and Adolf Martin Ritter, Patristische Texte und Studien 36, Berlin, New York: De Gruyter 1991/ reprint 2014 and as vol. 67, 2012.

[24] Heil, G, Ritter, AM. (Eds.). Pseudo-Dionysius Areopagita. De Coelesti Hierarchia, De Ecclesiastica Hierarchia, De Mystica Theologia, Epistulae: 2 (vol. 67). Walter de Gruyter, 2012.

[25] Lampe, Geoffrey WH, and Geoffrey W. Lampe. A patristic Greek lexicon. Clarendon Press, 1961.

[26] Rorem, P. Pseudo-Dionysius: A Commentary on the Texts and an Introduction to their Influence. Oxford University Press,1993.

[27] PG 151:12B, 200D

[28] Brock, SP. A short Melkite baptismal service in Syriac, 2010.

[29] Angold, M. (ed.), The Byzantine Aristocracy IX to Xlll Centuries, Oxford: B.A.R International Series 221, 1984.

[30] Beard, M, Henderson J. "Cappadocians at Court: Diogenes and Timarion", in M. Mullett and D. Smythe (ed.), Alexios 1 Komnenos, BBTT (Papers of the second Belfast Byzantine International Colloquium, 14-16 April, 1989) 4.1, Belfast, pp. 329-338, 1996.

[31] Beaton, R, Ricks D. "Digenis Akritis: new approaches to Byzantine poetry." Aldershot: Ashgate, pp. 103-115,1993.

[32] Cameron, A. Byzantine Matters, Princeton: Princeton University Press, 2014.

[33] Cheynet, JC. "L'aristocratie cappadocienne aux Xe et Xle siècles", Dossiers d'Archéologie 233, pp. 42-49, 2003

[34] Cormack, R. Byzantine Art, Oxford: Oxford University Press, 2000

[35] Cormack, R. "Aristocratic Patronage of the Arts in the 11th and 12th century Byzantium", in M. Angold, (ed.), The Byzantine Aristocracy IX to X11l Centuries, Oxford: B.A.R International Series 221, pp. 158$172,1984$.

[36] Corpus Inscriptionum Graecarum (CIG), initially edited by August Böckh, 1828-1877, vols. 1-13.

[37] Decker, M, JE. Cooper, Life and society in Byzantine Cappadocia, Basingstoke: Palgrave Macmillan, 2012.

[38] Ene D-Vasilescu, E. "Shrines and Schools in Byzantine Cappadocia", Journal of Early Christian History, 9: (1) pp. 1-29, 2019.

[39] Ertuğ, A, Jolivet-Lévy C. Sacred art of Cappadocia: Byzantine murals from the 6th to 13th centuries, Istanbul: Ertuğ \& Kocabiyık, 2006.

[40] Giovannini, L. (ed.), Arts de Cappadoce, Genève: Nagel, 1971.

[41] Grabar, A. Christian iconography: a study of its origins, Routledge and Kegan Paul, London, 1969.

[42] Öztürk FG. "Açiksaray 'Open Palace': a Byzantine rock-cut settlement in Cappadocia", Byzantinische Zeitschrift, Bd. 107/2, I. Abteilung, 2014.

[43] Haldon, JF, Kennedy H. "The arab-byzantine frontier in the eighth and ninth centuries: military organisation and society in the borderlands", Zbornik Radova Vizantoloskog Instituta 19, pp. 79-116, 1980.

[44] Hendy, MF. in Studies in the Byzantine monetary economy, c. 3001450, Cambridge, UK: Cambridge University Press, 1985.

[45] Herrin, J. Byzantium: The Surprising Life of a Medieval Empire, Princeton: Princeton University Press, 2007.

[46] Hild, F, Restle M., Kappadokien (Kappadokia, Charsianon, Sebasteia und Lykandos) [Tabula Imperii Byzantini 2], Vienna, 1981.

[47] Hunt, L-A. "Comnenian Aristocratic Palace Decoration: Descriptions and Islamic connections", in M. Angold, (ed.), The Byzantine Aristocracy IX to Xlll Centuries, Oxford: B. A.R International Series 221, pp. 138-157, 1984.

[48] Jeffreys, E. Digenis Akritis: the Grottaferrata and Escorial Versions, Cambridge: Cambridge University Press, 1998.

[49] Jerphanion, G. de, Un nouvelle province de l'art byzantine. Les églises rupestres du Cappadoce, Paris: Paul Geuthner, vol. 1,1925.

see the reference [26]. For the bath of divine generation in Gregory Palamas see the reference [28], where the baptised are reborn in a 'divine way not through the desire of the flesh or the will of a man but through Christ'. For rebirth through Baptism, see the reference [29]. 
[50] Jerphanion, G. de, "Mellanges d'archeologie anatolienne: monuments préhelléniques, gréco-romains, byzantins et musulmans de Pont, de Cappadoce et de Galatie”, MelUSJ X11l, Beyrouth: Impr. Catholique, 1928.

[51] Jolivet-Lévy, C. Études cappadociennes, London: Pindar Press, 2002.

[52] Jolivet-Lévy, C, Savageot C. La Cappadoce médiévale: images et spiritualité, Zodiaque, Saint-Léger-Vauban, 2001.

[53] Jolivet-Lévy C, Savageot C. L'arte della Cappadocia, Milano: Jaca Book, 2001.

[54] Kalas, V. "Early Explorations of Cappadocia and the Monastic Myth", in Byzantine and Modern Greek Studies 28, pp. 101-119, 2004.

[55] Kalas, V. "Challanging the Sacred Landscape of Byzantine Cappadocia", in A. Walker and A. Luyster (eds.), Negotiating Secular and Sacred in Medieval Art, Ashgate, Aldershot, 147-173, 2009.

[56] Kalas, V."Cappadocia”, Encyclopedia of Monasticism, in W. M. Johnson, Chicago, pp. 238-239, 2000.

[57] Kalas, V. "Rock-Cut Architecture of the Peristrema Valley: Society and Settlement in Byzantine Cappadocia", doctoral dissertation, New York University, New York, 2000.

[58] Kaplan, M. "Les grand proprietaries du Cappadoce (V1- Vlle siècle)", in C. D. Fonseca (ed.), Le aree omogeneé della civiltà rupestre nell'ambito dell'Impero bizantino: La Cappadocia, Galatina, pp. 125$158,1981$.

[59] Kitzinger, E. "Byzantine art in the period between Justinian and iconoclasm," in Les Actes du Xl e Congress International d'Études bizantines, Münich, pp. 1-50, 1958.

[60] Kostof, S. Caves of God. The Monastic Environment of Byzantine Cappadocia, Cambridge, Mass., 1972 (éd. révisée sous le titre Caves of God. Cappadocia and its Churches, Oxford/ New York/Toronto, 1989.

[61] Lafontaine-Dosogne, J. Iconographie de l'enfance de la Vierge dans l'empire byzantin et en Occident, vol. 1, 1964.

[62] Laiou, AE. (ed.), The Economic History of Byzantium from the Seventh through the Fifteenth Century, Cambridge, MA: Harvard University Press, Dumbarton Oaks Studies, 2002.

[63] Laiou, AE, Morrison C. The Byzantine Economy, Cambridge, UK: Cambridge University Press, 2007.

[64] Magdalino, P. “The Byzantine Aristocratic Oikos”, in M. Angold, (ed.), The Byzantine Aristocracy IX to X1ll Centuries, Oxford: B. A.R International Series 221, pp. 92-112, 1984.

[65] Mango, C. The Art of the Byzantine Empire, 312-1453: Sources and Documents, Englewood Cliffs, N.J: Prentice-Hall; reprinted by University of Toronto Press, Toronto, Buffalo and London, 1972 and 1986.

[66] Mateo-Seco, LF, Maspero G. (eds.), The Brill Dictionary of Gregory of Nyssa, Leiden, Boston: Brill, 2010.

[67] Morris, R. "The Byzantine Aristocracy and the monasteries", in M. Angold, (ed.), The Byzantine Aristocracy 1X to X11l Centuries, Oxford: B. A.R International Series 221, pp. 112-138, 1984.

[68] Mundell Mango, M. (ed.), Byzantine Trade, 4th-12th Centuries: The Archaeology of Local, Regional and International Exchange, Society for the Promotion of Byzantine Studies. Publications vol. 14, Ashgate, Farnham, 2009.

[69] Orientalia Christiana, Pontificium Institutum Orientalium Studiorum/ Pontifical Oriental Institute, Rome.

[70] Ousterhout, RG. "Questioning the Architectural Evidence: Cappadocian monasticism", in M. Mullet and A. Kirby (eds.), Work and Worship at the Theotokos Evergetis, 1050-1200, Belfast, pp. 420431, 1997.

[71] Öztürk, GF. “Açıksaray ‘Open Palace’: a Byzantine rock-cut settlement in Cappadocia”, Byzantinische Zeitschrift, Bd. 107/2, I. Abteilung, 2014.

[72] Pekak, MS. “Ürgüp, Yeşilöz, (Tağar) Kilisesi”, Hacettepe Üniversitesi Edebiyat

[73] Fakültesi Dergisi XXVII.I, 203-218, 2010.

[74] Peker, N. "Gülşehir Karşı Kilise Duvar Resimleri”, in A. Odekan; E. Akyürek, and N. Necipoğlu (eds.), I. Uluslararası Sevgi Gönül Bizans Araştırmaları Sempozyumu, 572-581, 2010.

[75] Peker, N, Uyar BT. "Güzelgöz-Başköy ve Çevresi Bizans Dönem Yerleșimleri 2012”, AST XXXI.II 110-120, 2013.

[76] Pentcheva, BV. "Rhetorical images of the Virgin: the icon of the usual miracle at the Blachernai", Journal for Anthropology and Aesthetics XXXVII 34-56,2000.

[77] Petzold, L. "Nikolaos von Myra (von Bari)", Lexikon der Christliischen Ikonographie VIII, 45-58, 1976.

[78] Restle, M. Byzantine Wall Painting in Asia Minor I- II, 1967; vol. 3, translated from German by Irene R. Gibbons, Greenwich, CT: New York Graphic Society Ltd., 1969.
[79] Rhoby, A. Inscriptions in Byzantium and beyond: methods - projects case studies, International Congress of Byzantine Studies (22nd: Sofia, Bulgaria), Vienna: Verlag der Österreichischen Akademie der Wissenschaften, OAW, 2015.

[80] Rodley, L. Cave Monasteries of Byzantine Cappadocia, Cambridge: Cambridge University Press, 1985.

[81] Rodley, L. "The Pigeon House Church, Çavuşin”, Jahrbuch der Österreichischen Byzantinischen Gesellschaft XXXIII, 301-339, 1983.

[82] Serdar, M. "Semavi Dinlerde Dört Büyük Melek (Cebrail, Mikail, İsrafil, Azrail)", Frrat Üniversitesi İlahiyat Fakültesi Dergisi XIII.II, 227-245, 2008

[83] Schiller, G. Iconography of Christian Art I, New York: New York Graphic Society, 1966.

[84] Schiller, G. Iconography of Christian Art II, New York: New York Graphic Society, 1971

[85] Stierlin, H., Orient Byzantin, L’Art Antiqueau Proche-Orient, Paris Seuil, 1988

[86] Soykan, AN. Aksaray-Belisirma: Karagedik Kilise, Istanbul: Arkeoloji ve Sanat Yayinlari, 2017

[87] Supplementum Epigraphicum Graecum, Leiden, Boston: Brill, 1950present.

[88] Thierry, N. "La Cappadoce de l'antiquité au moyen âge," Melanges de l'Ecole francaise de Rome. Moyen Age, vol. 110, no. 2 (1998), pp. 867 897; republished in Bibliothèque de l'Antiquité tardive 4, Turnhout: Brepols, 2002.

[89] Thierry, N. "L'iconographie capadocienne de l'affront fait à Anne d'après le Protévangile de Jacques", Apocrypha 7, 261-272, 1996.

[90] Thierry, N. Haut Moyen Âge en Cappadoce. Les églises de la région de Cavuşin, Paris: Éditions du Centre National de la Recherche, vols. 1-2, 1983, 1994.

[91] Thierry, N. "Yusuf Koç Kilisesi, Eglise Rupestre de Cappadoce", in Mélanges.

[92] Mansel I, 193-206, 1974

[93] Thierry, N. Art byzantin du haut moyen-âge en Cappadoce: l'église no. 3 de Mavrucan, Paris: Éditions Klincksieck, 1972.

[94] Thierry, N. Les peintures murales de six églises du haut moyen âge en Cappadoce,

[95] Académie des inscriptions \& belles-lettres, Paris: Éditions Klincksieck, 1971.

[96] Thierry, N. "Le culte de la croix dans l'empire byzantin du VIIe siècle au Xe dans ses rapports avec la guerre contre l'Infidèle. Nouveaux témoignages archéologiques", Miscellanea Agostino P emisi, 1, Rivista di Studi Bizantini e Slavi 1, 205-228, 1981.

[97] Thierry, N. "L'iconoclasme en Cappadoce d'après les sources archéologiques. Origines et modalités", Le Rayonnement grec. Hommages à Charles Delvoye, Bruxelles: pp. 389-403, 1982.

[98] Thierry, N, Thierry JM. Nouvelles églises rupestres de Cappadoce: region du Hasan Dağı, Paris: Librairie C. Klincksieck, 1963.

[99] Thierry, N, Thierry JM. "Eglise de Kizil-Tchoukour chapelle iconoclaste, chapelle de Joachim et d'Anne", in Monuments et mémoires de la Fondation Eugène Piot, Paris: Presses universitaires de France, vol. 50, 105-146, 1958

[100] Thierry, N, Thierry JM. "Iconographie inédite en Cappadoce. Le cycle de la conception et de l'enfance de la Vierge a Kizil-Tchoukour," in Akten des XI. Internationalen Byzantinistenkongressen München, Munich, 620-623, 1958.

[101]Thiery, N. "La Vierge de Tendresse a l'époque macédonienne”, Zograf 10, 57-70, 1979.

[102]Tran Tam Tinh, V, Labrecque Y. Isis lactans: Corpus des monuments gréco-romains d'Isis allaitant Harpocrate, Leiden: Brill, 1973.

[103]Ünal, C. Bizans Sanatında Meryem Eleousa Tasviri. Türk Bilim V (201): 73-87.

[104]Uyar, T. "Change in The Byzantine World in the Twelfth and Thirteenth Centuries", in A. Ödekan, E. Akyürek, and N. Necipoğlu (eds.), 1. Uluslararası Sevgi Gönül Bizans Araştırmaları Sempozyumu, 617-625, 2010

[105]Van Dam, R. Families and Friends in Late Roman Cappadocia, Philadelphia: University of Pennsylvania Press, 2003.

[106]Weitzman, K. "Byzantine Miniature and Icon Painting in the Eleventh Century", in J. M. Hussey, D. Obolensky, and S. Runciman (eds.), Proceedings of the XIII International Congress of Byzantine Studies, Oxford, 5.-10 September 1966 (1967): 207-224.

[107]Wharton- Epstein, A. "Rock-cut chapels in Göreme Valley, Cappadocia: The Yilanli group and the column churches", Cahiers archéologiques. Fin de l'antiquité et moyen-âge, vol. 24, 115-135, 1975. 